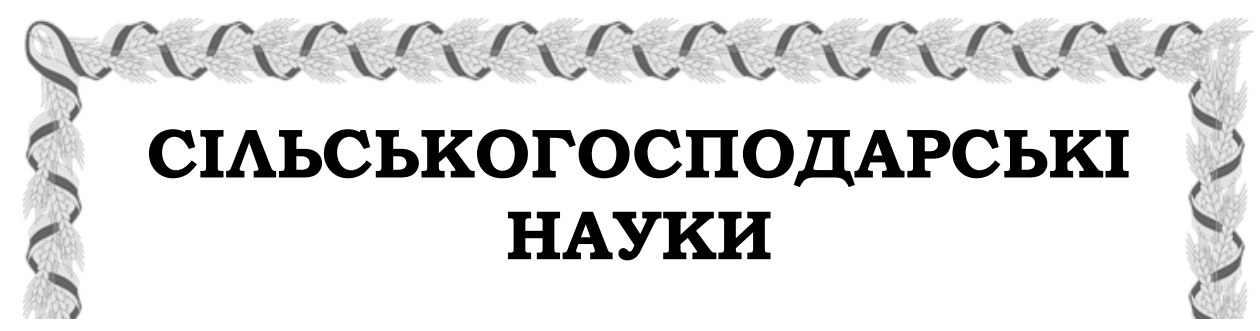

УДК 631.15:631.8:632.954

\author{
Асанішвілі Н.M. ${ }^{1}$ \\ канд. с.-г. наук, с.н.с. \\ учений секретар \\ E-mail : nadia-asanishvili@ukr.net \\ Буслаєва Н.Г. ${ }^{1}$ \\ канд. с.-г. наук., с.н.с. \\ старший науковий співробітник відділу інноваційної діяльності та економіки \\ E-mail : nataliyabuslaeva@ukr.net \\ Шляхтурова С.П. ${ }^{1}$ \\ науковий співробітник відділу адаптивних інтенсивних технологій \\ зернових колосових культур і кукурудзи \\ E-mail : stopasv@ukr.net \\ ${ }^{1}$ Національний науковий иентр «Інститут землеробства НААН» \\ смт Чабани Києво-Святошинського р-ну Київської обл., Украӥна

\section{ВПЛИВ АГРОХІМІЧНОГО НАВАНТАЖЕННЯ НА ЗАБЕЗПЕЧЕНІСТЬ РОСЛИН ЕЛЕМЕНТАМИ ЖИВЛЕННЯ ТА ВРОЖАЙНІСТЬ КУКУРУДЗИ В ЛІСОСТЕПУ}

\begin{abstract}
Анотація
У статті представлено результати досліджень з питань оптимізаиії забезпеченості рослин кукурудзи основними елементами живлення за різного агрохімічного навантаження в умовах Лісостепу. Метою досліджень було встановлення впливу різних норм мінеральних добрив та побічної продукиї попередника як добрива на забезпеченість рослин азотом, фосфором $і$ калієм та врожайність кукурудзи. Дослідження проводили впродовж 2016-2019 рр. на темно-сірому опідзоленому крупнопилувато-легкосуглинковому трунті Лісостепу із застосуванням польового, хімічного, розрахунково-вагового та математико-статистичного методів. Виявлено, що тривале вирощування сільськогосподарських культур впродовж 30 років за різного агрохімічного навантаження у сівозміні на темно-сірому опідзоленому крупнопилувато-легкосуглинковому трунті Лісостепу зумовило створення різних агрохімічних фонів. За результатами трунтової та рослинної діагностики встановлено, що азот $\epsilon$ лімітуючим елементом живлення за вирощування кукурудзи. У варіантах з унесенням підвищених $\left(N_{180} P_{120} K_{180}\right)$ та високих $\left(N_{240} P_{120} K_{240}\right)$ норм мінеральних добрив на фоні побічної продукції попередника (соломи пшенииі озимої), де сформована найвища врожайність кукурудзи - 11,21-12,10 m/2а, вміст рухомого фосфору в 0-20 см шарі трунту був дуже високим, рухомого калію - високим, азоту, шо легко гідролізується - дуже низьким. У иих варіантах рослини кукурудзи за стадіями ВВСН 16, 19 i 65 накопичували оптимальну кількість азоту, а за вмістом фосфору та калію виявлено оптимальну та високу їх забезпеченість впродовж вегетації за внесення мінеральних добрив у нормах понад $N_{60} P_{45} K_{60}$.
\end{abstract}


За результатами кореляційного та регресійного аналізу підтверджено визначальну роль азоту та калію у формуванні продуктивності кукурудзи. Побудовано математичні моделі, щзо дають можливість прогнозувати рівень врожайності кукурудзи залежно від вмісту хімічних елементів у трунті та рослинах вже на ранніх стадіях розвитку ВВСН.

Ключові слова: кукурудза, трунтова та рослинна діагностика, азот, фосфор, калій, врожайність, технологія вирощування.

Вступ. Кукурудза (Zea mays L.) - основна зернофуражна культура в Україні, посівні площі, врожайність та валові збори якої за останні десятиріччя зросли найбільше серед усіх сільськогосподарських культур. Досягнення високої врожайності кукурудзи можливе лише за найповнішого забезпечення потреби рослин в хімічних елементах живлення і $є$ основною передумовою реалізації генетичного потенціалу продуктивності гібридів [9]. Разом з тим, необхідно оптимізувати мінеральне живлення посівів кукурудзи для запобігання неефективного та надмірного застосування мінеральних добрив, що призводить до забруднення довкілля та зниження економічної доцільності технологій вирощування [5].

Аналіз останніх досліджень і публікацій. Відомо, що кукурудза на створення 1 т зерна з відповідною кількістю побічної продукції виносить з грунту в середньому 24-32 кг азоту, 10-14 кг фосфору, 25-35 кг калію [8]. Тому серед усіх елементів технології вирощування культури система удобрення $є$ найдієвішим чинником, що забезпечує високу окупність вкладених ресурсів.

Водночас, ефективність внесених органічних і мінеральних добрив значно різниться залежно від родючості грунту, вологозабезпеченості, температури, а також взаємодії з іншими елементами технології вирощування $[1,2]$. Зокрема, азотне удобрення на фоні фосфорно-калійного найефективнішим $\epsilon$ на дерново-підзолистих грунтах у північних регіонах зони кукурудзосіяння, а на темно-сірих лісових та чорноземних грунтах його ефективність суттєво знижується [12]. На лучно-чорноземному карбонатному грунті кукурудза позитивно реагує на комплексне удобрення й підвищення норми добрив до $\mathrm{N}_{135} \mathrm{P}_{135} \mathrm{~K}_{202}$, що $є$ дієвим фактором оптимізації калійного живлення рослин кукурудзи, підвищення урожайності та якості зерна, поліпшення калійного фонду грунту [14]. Фосфорне удобрення найменше впливає на врожайність кукурудзи через порівняно нижчу потребу культури у цьому елементі, а також через накопичення залишкових фосфатів у грунтах впродовж періоду інтенсивної хімізації сільського господарства. Разом з тим, на сьогодні внаслідок різкого зменшення обсягів внесення фосфорних добрив 53 \% грунтів характеризуються низьким і середнім вмістом $\mathrm{P}_{2} \mathrm{O}_{5}$ [11].

Діагностика мінерального живлення кукурудзи $€$ важливим чинником забезпечення відповідного агрохімічного навантаження технологій вирощування різної інтенсивності та включає грунтову та рослинну діагностику, результати якої взаємодоповнюють, але не заміняють одна одну. У класичних роботах вчених-агрохіміків розроблені нормативні параметри вмісту у грунті та рослинах або їх окремих індикаторних органах макро- i мікроелементів, за якими ідентифікують стан забезпеченості відповідними хімічними елементами у взаємозв'язку з урожайністю [10, $13,15]$.

Наразі продовжуються дослідження у цьому напрямі, що сприяє доповненню інформаційної бази діагностики мінерального живлення кукурудзи на різних грунтах та агрокліматичних зонах, а також проведення iї новітніми методами, зокрема аеродистанційного зондування та картографування $[3,4,6,7,14,16]$. Це дозволить здійснювати оптимізацію системи удобрення культури залежно від змінних чинників технології вирощування задля підвищення ефективності використання сортового, агрокліматичного та матеріально-технічного ресурсного потенціалу. 
Мета. Тому метою наших досліджень було встановлення впливу різних норм мінеральних добрив та побічної продукції попередника як добрива на забезпеченість рослин азотом, фосфором і калієм та врожайність кукурудзи в умовах Лісостепу.

Методологія досліджень. Польові дослідження проводили впродовж 2016-2019 pp. у чотирипільній короткоротаційній сівозміні довготривалого стаціонарного досліду ННЦ «Інститут землеробства НААН», що територіально розміщується у північній частині Лісостепу (смт. Чабани Києво-Святошинського р-ну Київської обл.). Дослід закладено у 1987 р. методом розщеплених ділянок згідно усіх вимог дослідної справи (Доспєхов Б. О.) на темно-сірому опідзоленому крупнопилувато-легкосуглинковому грунті.

У дослідженнях вивчали вплив різних норм мінеральних добрив та побічної продукції попередника (соломи пшениці озимої) на врожайність кукурудзи. Схему досліду наведено у табл. 1. Мінеральні добрива вносили у формі аміачної селітри (N $34 \%)$, амофосу $\left(\mathrm{P}_{2} \mathrm{O}_{5}-52 \%\right)$ та хлористого калію $\left(\mathrm{K}_{2} \mathrm{O}-60 \%\right)$. Система обробітку грунту включала: з осені лущення стерні і оранку на глибину 25-27 см, навесні - закриття вологи, проміжну культивацію та передпосівний обробіток на глибину заробки насіння.

Насіння перед сівбою обробляли стимулятором росту рослин (Регоплант 250 мл/т). Кукурудзу висівали після пшениці озимої з нормою висіву на густоту 80 тис. шт./га. Після сівби здійснювали обробку посівної площі грунтовим гербіцидом Примекстра Голд 720 (2,5 л/га). На стадії ВВСН 16 посіви кукурудзи обприскували баковою сумішшю: біостимулятор Стимпо (25 мл/га) + мікродобрива Фолік Макро $(2,0$ л/га) і Фолік Zn (0,5 л/га) + страховий гербіцид Майстер Пауер (1,25 л/га). Мікродобриво Фолік Zn містить цинк (20\%) та азот (8\%), Фолік Макро - $22 \%$ азоту, $22 \%$ фосфору, 17 \% калію, від 0,001 до 0,14 \% - бор, мідь, залізо, марганець, молібден, цинк. Усі препарати та добрива, що використовували у дослідженнях, занесені до Переліку пестицидів і агрохімікатів, дозволених для використання в Україні.

Погодні умови вегетаційного періоду кукурудзи впродовж років проведення досліджень відзначались перевищенням на 6-20 \% понад норму середньодобових температур повітря за випадання лише 47-73 \% опадів від середньобагаторічної норми 3 нерівномірністю їх розподілу за місяцями та декадами, що відповідним чином вплинуло на рівень врожайності культури. Найсприятливішими виявилися погодні умови вегетаційного періоду 2018 і, меншою мірою, 2019 рр., задовільними - 2017 і 2016 pp.

Для досягнення поставленої мети застосовували загальнонаукові та спеціальні методи досліджень: польовий - для вивчення взаємозв'язку об'єкта 3 біотичними та абіотичними факторами; хімічний - для визначення вмісту у рослинах кукурудзи за стадіями розвитку ВВСН загального азоту (методом К'єльдаля, ДСТУ ISO 5983:2003), фосфору - методом колориметрії та калію - полум'яно-фотометричним методом згідно 3 «Методами визначення вмісту загального азоту, фосфору, калію в одній витяжці рослинного матеріалу», ІГА ім. О. Н. Соколовського УААН, 1999 р.

Проби грунту для аналізу на вміст азоту, що легко гідролізується (за Корнфілдом, ДСТУ 7863:2015) та рухомих форм фосфору та калію (за Чириковим, ДСТУ 4115-2002) відбирали перед внесенням добрив та після збирання. Врожайність кукурудзи визначали ваговим методом, поділяночно, з урахуванням засміченості й вологості. Математикостатистичні методи застосовували для встановлення достовірності отриманих даних та виявлення залежностей між показниками.

Результати. Рівень родючості темно-сірого опідзоленого крупнопилуватолегкосуглинкового грунту в різних варіантах удобрення визначався прямою дією добрив, які застосовували безпосередньо під кукурудзу і післядією добрив, які вносили під попередник та передпопередник в сівозміні. Разом з тим, у різних варіантах удобрення 
внаслідок тривалого (з 1987 р.) ведення польового досліду з внесенням різних норм добрив створені відповідні агрохімічні фони (табл. 1).

Таблиця 1. Вміст у грунті легкогідролізованого азоту, рухомих фосфору та калію у полі під кукурудзою на зерно, середне за 2016-2018 рр., мг/кг

\begin{tabular}{|c|c|c|c|c|c|c|c|}
\hline \multirow{2}{*}{ Варіант удобрення } & \multirow{2}{*}{$\begin{array}{c}\text { Шар } \\
\text { грунту, см }\end{array}$} & \multicolumn{3}{|c|}{ Перед внесенням добрив } & \multicolumn{3}{|c|}{ Після збирання } \\
\hline & & $\mathrm{N}$ & $\mathrm{P}_{2} \mathrm{O}_{5}$ & $\mathrm{~K}_{2} \mathrm{O}$ & $\mathrm{N}$ & $\mathrm{P}_{2} \mathrm{O}_{5}$ & $\mathrm{~K}_{2} \mathrm{O}$ \\
\hline \multirow{3}{*}{$\begin{array}{l}\text { Без добрив } \\
\text { (контроль) }\end{array}$} & $0-20$ & 61,6 & 172,9 & 94,0 & 62,5 & 142,5 & 67,9 \\
\hline & $20-40$ & 55,1 & 162,6 & 74,6 & 46,7 & 125,0 & 60,0 \\
\hline & $40-60$ & 45,3 & 91,7 & 76,5 & 36,9 & 90,8 & 60,0 \\
\hline \multirow{3}{*}{$\begin{array}{l}\text { Побічна продукція } \\
\text { попередника (фон) }\end{array}$} & $0-20$ & 62,5 & 170,8 & 92,5 & 60,2 & 139,2 & 72,9 \\
\hline & $20-40$ & 55,1 & 150,0 & 85,0 & 45,3 & 115,4 & 61,0 \\
\hline & $40-60$ & 35,9 & 91,3 & 77,1 & 29,9 & 84,5 & 71,2 \\
\hline \multirow{3}{*}{$\mathrm{N}_{60} \mathrm{P}_{45} \mathrm{~K}_{60} *$} & $0-20$ & 66,7 & 185,0 & 96,7 & 61,1 & 172,9 & 87,9 \\
\hline & $20-40$ & 56,5 & 131,2 & 104,6 & 45,3 & 128,2 & 57,5 \\
\hline & $40-60$ & 37,8 & 90,8 & 81,1 & 29,4 & 85,0 & 58,9 \\
\hline \multirow{3}{*}{$\Phi$ ОH $+\mathrm{N}_{60} \mathrm{P}_{45} \mathrm{~K}_{60}$} & $0-20$ & 67,0 & 224,8 & 113,8 & 65,8 & 207,5 & 102,5 \\
\hline & $20-40$ & 56,0 & 182,5 & 88,1 & 55,4 & 154,1 & 83,3 \\
\hline & $40-60$ & 35,5 & 80,4 & 77,2 & 41,8 & 90,8 & 62,1 \\
\hline \multirow{3}{*}{$\Phi$ ОH $+\mathrm{N}_{120} \mathrm{P}_{45} \mathrm{~K}_{60} * *$} & $0-20$ & 74,7 & 304,7 & 202,9 & 67,7 & 308,8 & 120,8 \\
\hline & $20-40$ & 55,5 & 198,6 & 100,8 & 51,8 & 201,7 & 72,9 \\
\hline & $40-60$ & 33,1 & 83,8 & 78,4 & 31,3 & 100,8 & 62,1 \\
\hline \multirow{3}{*}{$\Phi$ ОH $+\mathrm{N}_{120} \mathrm{P}_{90} \mathrm{~K}_{120}$} & $0-20$ & 64,9 & 237,5 & 133,3 & 70,9 & 254,8 & 124,6 \\
\hline & $20-40$ & 49,9 & 195,8 & 93,0 & 49,5 & 161,0 & 61,3 \\
\hline & $40-60$ & 29,4 & 96,2 & 79,2 & 36,9 & 95,1 & 64,6 \\
\hline \multirow{3}{*}{ Фон $+\mathrm{N}_{180} \mathrm{P}_{120} \mathrm{~K}_{180}$} & $0-20$ & 71,4 & 345,0 & 163,0 & 65,3 & 266,7 & 159,6 \\
\hline & $20-40$ & 56,5 & 300,9 & 118,6 & 49,5 & 256,5 & 90,4 \\
\hline & $40-60$ & 41,5 & 149,4 & 87,1 & 30,3 & 105,0 & 64,8 \\
\hline \multirow{3}{*}{$\begin{array}{l}\text { Фон }+\mathrm{N}_{240} \mathrm{P}_{120} \mathrm{~K}_{240} \\
\text { (на } 10 \text { т/га) }\end{array}$} & $0-20$ & 70,5 & 261,5 & 163,4 & 85,4 & 274,6 & 150,0 \\
\hline & $20-40$ & 55,5 & 198,6 & 93,8 & 50,4 & 153,3 & 69,1 \\
\hline & $40-60$ & 34,1 & 90,5 & 80,6 & 32,2 & 87,3 & 60,0 \\
\hline \multirow{3}{*}{ Середнє } & $0-20$ & 67,4 & 237,8 & 132,4 & 67,4 & 220,9 & 110,8 \\
\hline & $20-40$ & 55,0 & 190,0 & 94,8 & 49,2 & 161,9 & 69,5 \\
\hline & $40-60$ & 36,6 & 96,8 & 79,6 & 33,6 & 92,4 & 63,0 \\
\hline \multirow{3}{*}{$S_{\bar{x}}$} & $0-20$ & 1,60 & 22,4 & 14,4 & 2,9 & 22,8 & 12,0 \\
\hline & $20-40$ & 0,76 & 18,10 & 4,73 & 1,22 & 16,54 & 4,25 \\
\hline & $40-60$ & 1,76 & 7,72 & 1,22 & 1,57 & 2,62 & 1,40 \\
\hline \multirow{3}{*}{$\mathrm{V}, \%$} & $0-20$ & 6,7 & 26,7 & 30,7 & 12,0 & 29,2 & 30,7 \\
\hline & $20-40$ & 3,9 & 26,9 & 14,1 & 7,0 & 28,9 & 17,3 \\
\hline & $40-60$ & 13,6 & 22,6 & 4,3 & 13,2 & 8,0 & 6,3 \\
\hline \multirow{3}{*}{ S } & $0-20$ & 4,5 & 63,5 & 40,6 & 8,1 & 64,5 & 34,0 \\
\hline & $20-40$ & 2,1 & 51,2 & 13,4 & 3,5 & 46,8 & 12,0 \\
\hline & $40-60$ & 5,0 & 21,8 & 3,4 & 4,4 & 7,4 & 4,0 \\
\hline
\end{tabular}

Примітка. *-до 2016 р. норма добрив $N_{120} P_{90} K_{120}$; **- впродовж 2011-2015 рр. норма добрив $N_{240} P_{120} K_{240}$. $S_{\bar{x}}$ - похибка середнього значення; $V$, \% - коефіцієнт варіаціï; $S$ - стандартне відхилення.

Найбільша диференціація впродовж цього періоду відбулася за вмістом фосфору та калію. Аналогічні результати отримано іншими науковцями за беззмінного вирощування кукурудзи впродовж 26 років на чорноземі типовому середньогумусному важкосуглинковому Лівобережного Лісостепу [6].

Найнижчий вміст легкогідролізованого азоту, рухомих фосфору та калію зафіксовано у контролі (без добрив), що пов'язано з багаторічним вирощуванням культур сівозміни на природному фоні родючості та відчуженням елементів живлення 3 основною і побічною продукцією, а найвищий - у варіантах з внесенням підвищених норм мінеральних добрив $\mathrm{N}_{180-240} \mathrm{P}_{120} \mathrm{~K}_{180-240}$. 
Встановлено, що за вмістом рухомих форм азоту, фосфору та калію згідно з ДСТУ 4362:2004 «Якість грунту. Показники родючості грунтів» азот знаходиться у першому мінімумі, адже навіть за внесення найвищих доз мінеральних добрив ступінь забезпеченості грунту його рухомими формами залишається дуже низьким (менше 100 мг/кг) зі значеннями у 0-20 см шарі 61,6-74,7 мг/кг, у 20-40 см - 49,9-56,5 мг/кг та 40-60 см - 29,4-45,3 мг/кг. Разом 3 тим, за оцінки забезпеченості необхідно врахувати, що відбір грунтових зразків проводили до внесення азотних добрив. Проте й після збирання кукурудзи вміст легкогідролізованого азоту у грунті був значно меншим, ніж 100 мг/кг.

Натомість за вмістом рухомого калію та особливо рухомого фосфору забезпеченість грунту класифікується як підвищена та висока, особливо у варіантах 3 унесенням високих норм фосфорних і калійних добрив.

Так, у шарі грунту 0-20 см перед сівбою містилося 92,5-202,9 мг/кг $\mathrm{K}_{2} \mathrm{O}$, після збирання - 67,9-159,9 мг/кг. Внесення мінеральних добрив у дозах $\mathrm{N}_{120} \mathrm{P}_{45} \mathrm{~K}_{60}$ i вище сприяло створенню агрохімічного фону з високим вмістом рухомого калію.

Грунт дослідної ділянки характеризується й переважно дуже високим вмістом рухомого фосфору. Навіть на контролі, де впродовж 30 років вирощували сільськогосподарські культури сівозміни без внесення мінеральних і органічних добрив вміст $\mathrm{P}_{2} \mathrm{O}_{5}$ був підвищеним (142,5-179,2 мг/кг у шарі 0-20 см), а у варіантах 3 внесенням мінеральних добрив у нормах від $\mathrm{N}_{60} \mathrm{P}_{45} \mathrm{~K}_{60}$ до $\mathrm{N}_{240} \mathrm{P}_{120} \mathrm{~K}_{240}$ він зростав до 172,9-345,0 мг/кг.

За профілем грунту у шарах 20-40 і 40-60 см вміст азоту, що легко гідролізується, рухомого фосфору та рухомого калію закономірно знижувався, проте закономірності залежності цих показників від агрохімічного навантаження були такими ж, як і в шарі 0$20 \mathrm{~cm}$.

За результатами статистичного аналізу встановлено, що рівень мінливості вмісту рухомого калію залежно від агрохімічного навантаження був найвищим у шарі грунту 020 см ( $\mathrm{V}=30,7 \%)$, знижуючись до середнього ( $\mathrm{V}=14,1-17,3 \%)$ та низького ( $\mathrm{V}=4,3-6,3 \%)$ у шарах 20-40 і 40-60 см. Вміст рухомого фосфору перед внесенням добрив характеризувався високою варіабельністю незалежно від шару грунту ( $\mathrm{V}=22,6-26,9$ \%), а у фазі повної стиглості зерна такий рівень мінливості показника зберігався лише у 0-40 см шарі (V=28,9-29,2 \%). Найнижчою в досліді була варіабельність вмісту азоту, що легко гідролізується. Про це свідчать коефіцієнти варіації, які знаходились у межах низького і середнього рівня V=3,9-13,6 і 7,0-13,2 \% за строками досліджень і профілем грунту.

Для оцінки ступеня забезпеченості культурних рослин грунтова діагностика повинна доповнюватися рослинною діагностикою, яку проводять у динаміці за основними стадіями розвитку. Відомими $\epsilon$ рівні-параметри вмісту макро- i мікроелементів в сільськогосподарських культурах, розроблені В. В. Церлінг для ідентифікації дуже низького, низького, оптимального та високого їх вмісту [15]. Для кукурудзи такі нормативні показники опрацьовані для фаз п'ять, дев'ять листків та цвітіння (стадії ВВСН 15, 19 та 65). Тому рослинну діагностику з метою встановлення рівня забезпеченості культури азотом, фосфором та калієм ми здійснювали саме за цими стадіями розвитку (табл. 2).

Встановлено, що вміст у рослинах кукурудзи $\mathrm{N}, \mathrm{P}_{2} \mathrm{O}_{5}, \mathrm{~K}_{2} \mathrm{O}$ залежав від норм внесених мінеральних добрив i закономірно знижувався зі старінням рослинного організму. Найвищі значення цих показників у межах стадій ВВСН зафіксовані у варіанті фон $+\mathrm{N}_{180} \mathrm{P}_{120} \mathrm{~K}_{180}$, причому зростання норми добрив до $\mathrm{N}_{240} \mathrm{P}_{120} \mathrm{~K}_{240}$ на фоні побічної продукції попередника не призводило до відповідного підвищення вмісту азоту, фосфору і калію у рослинах кукурудзи, ймовірно, через ефект «ростового розбавлення». 
Таблиця 2. Динаміка вмісту азоту, фосфору, калію в рослинах кукурудзи залежно від удобрення, середнс за 2016-2019 рр., \%

\begin{tabular}{|c|c|c|c|c|c|c|c|c|c|}
\hline \multirow{3}{*}{$\begin{array}{c}\text { Варіант } \\
\text { удобрення }\end{array}$} & \multicolumn{9}{|c|}{ Стадія ВBCH } \\
\hline & \multicolumn{3}{|c|}{15} & \multicolumn{3}{|c|}{19} & \multicolumn{3}{|c|}{65} \\
\hline & $\mathrm{N}$ & $\mathrm{P}_{2} \mathrm{O}_{5}$ & $\mathrm{~K}_{2} \mathrm{O}$ & $\mathrm{N}$ & $\mathrm{P}_{2} \mathrm{O}_{5}$ & $\mathrm{~K}_{2} \mathrm{O}$ & $\mathrm{N}$ & $\mathrm{P}_{2} \mathrm{O}_{5}$ & $\mathrm{~K}_{2} \mathrm{O}$ \\
\hline Без добрив (контроль) & 2,62 & 0,72 & 4,80 & 1,76 & 0,53 & 3,08 & 1,18 & 0,50 & 1,58 \\
\hline Фон & 2,68 & 0,68 & 3,96 & 1,82 & 0,55 & 2,89 & 1,21 & 0,49 & 1,50 \\
\hline $\mathrm{N}_{60} \mathrm{P}_{45} \mathrm{~K}_{60} *$ & 2,83 & 0,77 & 4,83 & 2,07 & 0,53 & 2,87 & 1,30 & 0,48 & 1,66 \\
\hline$\Phi \mathrm{OH}+\mathrm{N}_{60} \mathrm{P}_{45} \mathrm{~K}_{60}$ & 2,51 & 0,72 & 4,99 & 2,16 & 0,61 & 4,01 & 1,28 & 0,39 & 1,64 \\
\hline$\Phi \mathrm{OH}^{+} \mathrm{N}_{120} \mathrm{P}_{45} \mathrm{~K}_{60} * *$ & 2,95 & 0,76 & 5,41 & 2,03 & 0,55 & 4,24 & 1,74 & 0,59 & 1,89 \\
\hline$\Phi \mathrm{OH}^{+} \mathrm{N}_{120} \mathrm{P}_{90} \mathrm{~K}_{120}$ & 3,13 & 0,82 & 5,08 & 2,27 & 0,61 & 3,88 & 1,46 & 0,53 & 2,00 \\
\hline$\Phi \mathrm{OH}+\mathrm{N}_{180} \mathrm{P}_{120} \mathrm{~K}_{180}$ & 3,49 & 1,01 & 5,91 & 2,77 & 0,79 & 4,73 & 1,86 & 0,60 & 2,09 \\
\hline$\Phi$ он $+\mathrm{N}_{240} \mathrm{P}_{120} \mathrm{~K}_{240}($ на $10 \mathrm{t} / \mathrm{ra})$ & 3,00 & 0,83 & 5,93 & 2,65 & 0,65 & 3,96 & 1,75 & 0,48 & 2,07 \\
\hline Середнє & 2,90 & 0,79 & 5,11 & 2,19 & 0,60 & 3,71 & 1,47 & 0,51 & 1,80 \\
\hline$S_{\bar{x}}$ & 0,11 & 0,04 & 0,23 & 0,13 & 0,03 & 0,24 & 0,10 & 0,02 & 0,08 \\
\hline $\mathrm{V}, \%$ & 10,9 & 13,0 & 12,6 & 16,5 & 14,5 & 18,5 & 18,5 & 13,2 & 13,1 \\
\hline $\mathrm{S}$ & 0,3 & 0,1 & 0,6 & 0,4 & 0,1 & 0,7 & 0,3 & 0,1 & 0,2 \\
\hline
\end{tabular}

Примітка. *- до 2016 р. норма добрив $N_{120} P_{90} K_{120}$; **- впродовж 2011-2015 рр. норма добрив $\mathrm{N}_{240} P_{120} K_{240}$.

Так, за внесення розрахованої балансовим методом норми мінеральних добрив $\mathrm{N}_{240} \mathrm{P}_{120} \mathrm{~K}_{240}$ на планову врожайність 10 т/га у середньому за 2016-2019 рр. отримано на 21 $\%$ більше - 12,1 т/га зерна (рис. 1).

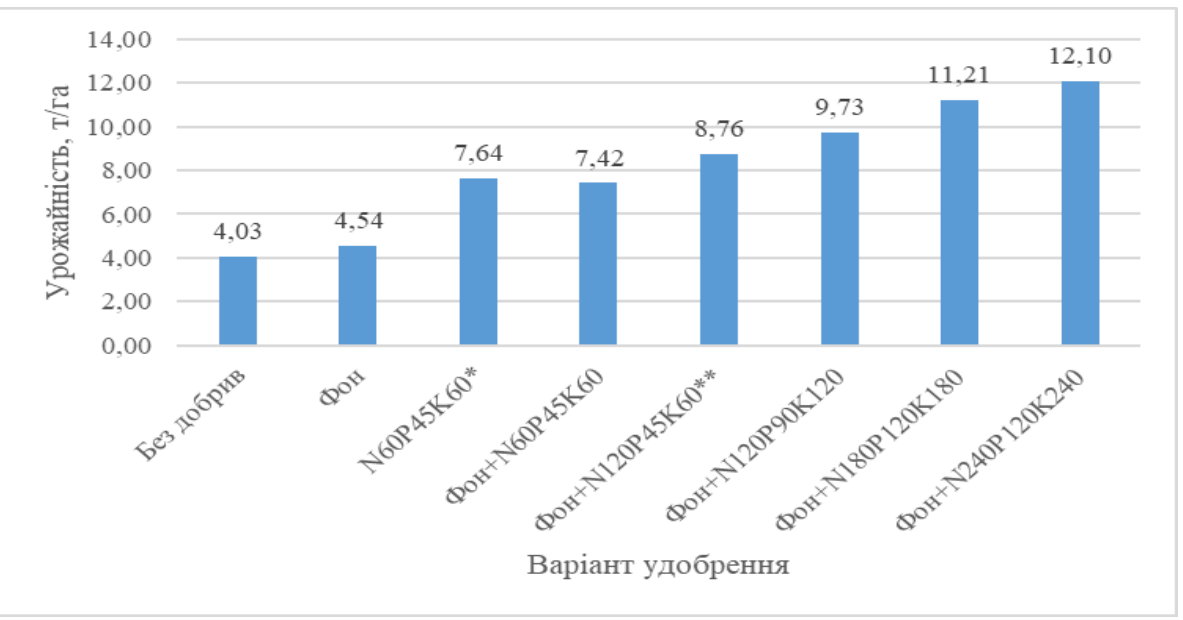

\section{Рис. 1. Урожайність кукурудзи на зерно залежно від агрохімічного навантаження} (середне за 2016-2019 рр.), т/га

Примітка. HIPo5=0,34 m/2a; * - до 2016 р. норма добрив $N_{120} P_{90} K_{120}$; ** - впродовж 2011 2015 рр. норма добрив $N_{240} P_{120} K_{240}$.

Порівняння отриманих результатів вмісту в рослинах $\mathrm{N}, \mathrm{P}_{2} \mathrm{O}_{5}, \mathrm{~K}_{2} \mathrm{O} 3$ рівнямипараметрами їх вмісту за В. В. Церлінг показало, що на стадії ВВСН 15 забезпеченість рослин за азотом була оптимальною або наближеною до такої за удобрення у нормах $\mathrm{N}_{120} \mathrm{P}_{90} \mathrm{~K}_{120}$ і вище, на стадії $19-\mathrm{N}_{180} \mathrm{P}_{120} \mathrm{~K}_{180}$ і вище, а найкращою - на стадії ВВСН 65 у фазі цвітіння, коли під ці параметри підпадали варіанти з удобренням у нормах вище $\mathrm{N}_{120} \mathrm{P}_{45} \mathrm{~K}_{60}$.За вмістом фосфору та калію в рослинах кукурудзи виявлено їх оптимальну та 
Подільський вісник: сільське господарство,

техніка, економіка
Podilian Bulletin: agriculture, engineering, economics

високу забезпеченість впродовж вегетації за інтенсивних технологій 3 унесенням мінеральних добрив у нормах понад $\mathrm{N}_{60} \mathrm{P}_{45} \mathrm{~K}_{60}$, що підтверджує результати грунтової діагностики.

Варіабельність показників вмісту азоту, фосфору та калію в рослинах кукурудзи на усіх стадіях розвитку відповідала середньому рівню, проте порівняно меншою вона була на стадії ВВСН 15 (V=10,9-13,0 \%), на стадіях 19 і 65 збільшувалась до $\mathrm{V=14,5-18,5}$ та 13,1-18,5 \%, що свідчить про посилення диференціації забезпеченості культури залежно від агрохімічного навантаження технології вирощування культури.

Врожайність кукурудзи за варіантами удобрення зростала 3 4,03 у контролі (без добрив) до 12,10 т/га - за максимальної у досліді норми $\mathrm{N}_{240} \mathrm{P}_{120} \mathrm{~K}_{240}$ на фоні побічної продукції попередника (див. рис. 1). ІІї зниження до $\mathrm{N}_{180} \mathrm{P}_{120} \mathrm{~K}_{180}$ i $\mathrm{N}_{120} \mathrm{P}_{90} \mathrm{~K}_{120}$ зумовило отримання відповідно 11,21 і 9,73 т/га зерна, а окупність добрив зерном зростала з 13,4 до 14,9 і 17,2 г/кг.

Для характеристики залежностей між врожайністю та вмістом макроелементів у грунті та рослинах кукурудзи проводили кореляційний аналіз відповідних показників, та за умови встановлення тісного зв'язку -кореляційно-регресійний аналіз та математичне моделювання з метою прогнозування рівня господарської врожайності. Виявлено прямі тісні кореляційні зв'язки між урожайністю та вмістом рухомих форм основних макроелементів у шарі грунту 0-20 см, що суттєво послаблювались за профілем грунту (табл. 3).

Таблиця 3. Кореляційні зв'язки між урожайністю та вмістом у грунті легкогідролізованого азоту, рухомих фосфору та калію у полі під кукурудзою на зерно, середнє за 2016-2019 рр.

\begin{tabular}{|c|c|c|c|c|c|c|c|c|}
\hline \multicolumn{9}{|c|}{ Шар грунту, см } \\
\hline \multicolumn{3}{|c|}{$0-20$} & \multicolumn{3}{|c|}{$20-40$} & \multicolumn{3}{|c|}{$40-60$} \\
\hline $\mathrm{N}$ & $\mathrm{P}_{2} \mathrm{O}_{5}$ & $\mathrm{~K}_{2} \mathrm{O}$ & $\mathrm{N}$ & $\mathrm{P}_{2} \mathrm{O}_{5}$ & $\mathrm{~K}_{2} \mathrm{O}$ & $\mathrm{N}$ & $\mathrm{P}_{2} \mathrm{O}_{5}$ & $\mathrm{~K}_{2} \mathrm{O}$ \\
\hline \multicolumn{9}{|c|}{ Перед внесенням добрив } \\
\hline 0,733 & 0,784 & 0,722 & $-0,080$ & 0,656 & 0,695 & $-0,412$ & 0,414 & 0,694 \\
\hline \multicolumn{9}{|c|}{ Після збирання } \\
\hline 0,737 & 0,850 & 0,964 & 0,422 & 0,655 & 0,482 & $-0,176$ & 0,452 & $-0,235$ \\
\hline
\end{tabular}

За фосфором та калієм кореляційні залежності були тіснішими порівняно з азотом, що пояснюється практично повним його споживанням культурою на формування основної та побічної продукції кукурудзи.

Оскільки найтіснішими кореляційні зв'язки між урожайністю та вмістом легкогідролізованого азоту, рухомих фосфору та калію були саме у 0-20 см шарі грунту $(\mathrm{r}=0,722-0,964)$, то математичні моделі 3 метою прогнозування господарської врожайності залежно від вмісту хімічних елементів живлення будували саме для цього шару грунту (табл. 4).

Таблиця 4. Залежність урожайності кукурудзи від вмісту легкогідролізованого азоту, рухомих фосфору та калію у 0-20 см шарі грунту

\begin{tabular}{|l|l|c|c|}
\hline \multicolumn{1}{|c|}{ Період } & \multicolumn{1}{|c|}{ Рівняння регресії } & $\mathrm{R}$ & $\mathrm{D}, \%$ \\
\hline $\begin{array}{l}\text { Перед } \\
\text { внесенням } \\
\text { добрив }\end{array}$ & $\begin{array}{l}\mathrm{Y}=-597,3283+18,1142 \mathrm{X}_{1}-0,1345 \mathrm{X}_{1}{ }^{2}-0,2746 \mathrm{X}_{2}+0,0005 \mathrm{X}_{2}{ }^{2}+ \\
0,3961 \mathrm{X}_{3}-0,0010 \mathrm{X}_{3}{ }^{2}\end{array}$ & 0,997 & 99,4 \\
\hline Після збирання & $\begin{array}{l}\mathrm{Y}=15,8027-1,6328 \mathrm{X}_{1}+0,0113 \mathrm{X}_{1}{ }^{2}-0,1656 \mathrm{X}_{2}+5,2673 \mathrm{X}_{2}{ }^{0,5}+ \\
0,1211 \mathrm{X}_{3}-0,0003 \mathrm{X}_{3}^{2}\end{array}$ & 0,992 & 98,4 \\
\hline
\end{tabular}

Примітка. $Y$ - урожайність, $m / 2 a ; X_{1}$ - вміст азоту, що легко гідролізується, мг/кг; $X_{2}-$ вміст рухомого фосфору, мг/кг; $X_{3}$ - вміст рухомого калію, мг/кг; $R$ - множинний коефіиієнт кореляції; $D$ - коефіцієнт детермінації. 
До того ж, це організаційно спрощує здійснення такого аналізу та є ефективним як у виробничих умовах, так і за проведення наукових досліджень. Тіснота зв'язку між урожайністю та основними агрохімічними властивостями грунту наближалась до 13 $\mathrm{R}=0,992-0,997$, а урожайність кукурудзи на 98,4-99,4 \% визначалась зміною вмісту легкогідролізованого азоту та рухомих фосфору і калію в грунті, що свідчить про високу достовірність розрахованих рівнянь регресії.

За результатами кореляційного аналізу показників рослинної діагностики встановлено, що найтіснішими зв'язки між урожайністю кукурудзи та вмістом хімічних елементів в рослинах були: за азотом - на стадії ВВСН 19 (r=0,929); фосфором - на стадії ВВСН 15 (r=0,771); калієм - ВВСН 65 (r=0,943) (табл. 5).

Таблиця 5. Кореляційні зв'язки між урожайністю та вмістом азоту, фосфору, калію в рослинах кукурудзи за стадіями розвитку залежно від удобрення, середнс за 20162019 pp.

\begin{tabular}{|c|c|c|c|c|c|c|c|c|}
\hline \multicolumn{3}{|c|}{ BBCH 15 } & \multicolumn{3}{c|}{ BBCH 19 } & \multicolumn{3}{c|}{ BBCH 65 } \\
\hline $\mathrm{N}$ & $\mathrm{P}_{2} \mathrm{O}_{5}$ & $\mathrm{~K}_{2} \mathrm{O}$ & $\mathrm{N}$ & $\mathrm{P}_{2} \mathrm{O}_{5}$ & $\mathrm{~K}_{2} \mathrm{O}$ & $\mathrm{N}$ & $\mathrm{P}_{2} \mathrm{O}_{5}$ & $\mathrm{~K}_{2} \mathrm{O}$ \\
\hline 0,760 & 0,771 & 0,878 & 0,929 & 0,712 & 0,755 & 0,870 & 0,334 & 0,943 \\
\hline
\end{tabular}

Разом 3 тим, кореляційні зв'язки в усіх випадках були прямими та тісними, крім зв'язку середньої сили $3 \mathrm{r}=0,334$ між урожайністю та вмістом фосфору на стадії ВВСН 65 (фаза цвітіння), що підтверджує визначальну роль азоту та калію у формуванні врожайності кукурудзи. Ці результати кореспондуються з даними, отриманими в умовах степової зони Чабаном В. І. зі співавторами [16].

3 урахуванням результатів кореляційного аналізу побудовано математичні моделі, що дають можливість на високому рівні ймовірності розрахувати рівень врожайності кукурудзи залежно від вмісту цих хімічних елементів в рослинах за стадіями розвитку ВВСН (табл. 6).

Так, рівень врожайності кукурудзи на 91,6-93,7 \% зумовлений варіацією вмісту азоту, фосфору та калію в рослинах. Зв'язок між урожайністю та змінними показниками вмісту хімічних елементів в рослинах був тісним, про що свідчить множинний коефіцієнт кореляції $\mathrm{R}=0,957-0,968$.

Таблиця 6. Математичні моделі залежності урожайності зерна кукурудзи від вмісту азоту, фосфору та калію в рослинах, середне за 2016-2019 рр.

\begin{tabular}{|c|l|c|c|}
\hline $\begin{array}{c}\text { Стадія } \\
\text { ВВСН }\end{array}$ & \multicolumn{1}{|c|}{ Рівняння регресії } & $\mathrm{R}$ & $\mathrm{D}, \%$ \\
\hline 15 & $\begin{array}{l}\mathrm{Y}=47,8559-111,9590 \mathrm{X}_{1}+20,0041 \mathrm{X}_{1}{ }^{2}+444,6601 \mathrm{X}_{2}-271,2632 \mathrm{X}_{2}{ }^{2}- \\
27,6893 \mathrm{X}_{3}+2,9102 \mathrm{X}_{3}{ }^{2}\end{array}$ & 0,968 & 93,7 \\
\hline 19 & $\mathrm{Y}=-44,7847+32,3840 \mathrm{X}_{1}-5,5565 \mathrm{X}_{1}{ }^{2}+4,8959 \mathrm{X}_{3}-0,6240 \mathrm{X}_{3}{ }^{2}$ & 0,967 & 93,5 \\
\hline 65 & $\mathrm{Y}=-22,5945+60,7804 \mathrm{X}_{1}-18,7749 \mathrm{X}_{1}{ }^{2}-25,7852 \mathrm{X}_{3}+8,9985 \mathrm{X}_{3}^{2}$ & 0,957 & 91,6 \\
\hline
\end{tabular}

Примітка. $Y$-урожайність, m/га; $X_{1}-$ вміст азоту, \%; $X_{2}-$ вміст фосфору, $\% ; X_{3}$ - вміст калію, \%.

Побудовані моделі дають можливість прогнозувати врожайність кукурудзи за аналогічних умов починаючи вже з ранніх стадій розвитку. Разом 3 тим, такий прогноз справджуватиметься за умови відсутності екстремальних погодних явищ або інших стресових впливів на агроценоз кукурудзи.

Висновки і перспективи. Тривале вирощування сільськогосподарських культур впродовж 30 років за різного агрохімічного навантаження у сівозміні на темно-сірому опідзоленому крупнопилувато-легкосуглинковому грунті Лісостепу зумовило створення різних агрохімічних фонів та диференціацію поживного режиму. За результатами 
грунтової та рослинної діагностики встановлено, що азот $є$ лімітуючим елементом живлення і знаходиться у першому мінімумі за вирощування кукурудзи.

$\mathrm{У}$ варіантах 3 унесенням підвищених $\left(\mathrm{N}_{180} \mathrm{P}_{120} \mathrm{~K}_{180}\right)$ та високих $\left(\mathrm{N}_{240} \mathrm{P}_{120} \mathrm{~K}_{240}\right)$ норм мінеральних добрив на фоні побічної продукції попередника (соломи пшениці озимої), де сформована найвища врожайність кукурудзи - 11,21-12,10 т/га, вміст рухомого фосфору в 0-20 см шарі грунту був дуже високим і становив 261,5-345,0 мг/кг, рухомого калію високим 3 умістом 150,0-163,4 мг/кг, а легкогідролізованого азоту - дуже низьким 3 умістом 65,3-85,4 мг/кг. У цих варіантах удобрення рослини кукурудзи за стадіями $\mathrm{BBCH} 16,19$ і 65 накопичували оптимальну кількість азоту - 3,00-3,49; 2,65-2,77 і 1,75$1,86 \%$, а за вмістом фосфору та калію виявлено оптимальну та високу їх забезпеченість впродовж вегетації за внесення мінеральних добрив у нормах понад $\mathrm{N}_{60} \mathrm{P}_{45} \mathrm{~K}_{60}$.

Встановлено тісні кореляційні залежності між урожайністю та вмістом легкогідролізованого азоту, рухомих фосфору та калію у 0-20 см шарі (r=0,722-0,964), тіснота яких послаблювалася за профілем грунту. Найтісніші кореляційні зв'язки між урожайністю та вмістом у рослинах впродовж вегетації виявлено за азотом та калієм (r=0,760-0,929 і 0,755-0,943), що підтверджує визначальну роль цих елементів у формуванні продуктивності кукурудзи.

Побудовано математичні моделі, що дають можливість на високому рівні ймовірності прогнозувати рівень врожайності кукурудзи залежно від вмісту хімічних елементів у грунті та рослинах вже на ранніх стадіях розвитку ВВСН.

Результати досліджень використано 3 метою раціонального застосування мінеральних добрив у технологіях вирощування кукурудзи 3 різним агрохімічним навантаженням в умовах Лісостепу, що сприятиме ефективному використанню виробничих і агрокліматичних ресурсів.

\section{Список використаних джерел}

1. Бережняк $€$. М. Ефективність альтернативних систем удобрення за різного обробітку в ланці польової сівозміни. Наукові прачі Інституту біоенергетичних культур і иукрових буряків: зб. наук. пращь. 2013. Вип. 17. Т. ІІ. С. 110-113.

2. Бикін А. В., Тарасенко О. В. Вплив удобрення на продуктивність кукурудзи на зерно за прямої сівби. Наукові доповіді Національного університету біоресурсів і природокористування України. 2014. № 3.

Режим доступу: http://nbuv.gov.ua/UJRN/Nd_2014_3_11

3. Броннікова Л. Ф. Формування азотного поживного режиму грунту при вирощуванні кукурудзи на зерно. Сільське господарство та лісівництво. 2018. № 1(8). С. 50-59.

4. Дёмин Е. А., Еремин Д. И. Азотный режим кукурузы, выращенной по зерновой технологии в лесостепной зоне Зауралья. Вестник Алтайского государственного аграрного университета. 2017. № 12 (158). С. 10-16.

5. Кореньков Д. А. Минеральные удобрения при интенсивных технологиях. Москва: Росагропромиздат, 1990. 192 с.

6. Кохан А. В., Глущенко Л. Д., Лень О. І. та ін. Продуктивність сортів і гібридів кукурудзи за різних систем удобрення та беззмінного їх вирощування. Вісник аграрної науки. 2019. №10 (799). C. $18-23$.

7. Крамарев С.М., Скрипник Л.Н., Артеменко С.Ф., Федорченко Ю.Н. и др. Диагностика минерального питания кукурузы. Вісник Полтавської держсавної аграрної академії. 2010. № 2. С. 617.

8. Наукові основи ведення зернового господарства / В. Ф. Сайко, М. Г. Лобас, І. В. Яшовський та ін.; За ред. В. Ф. Сайка. Київ: Урожай, 1994. 336 с.

9. Наукові основи ефективності використання виробничих ресурсів у різних моделях технологій вирощування зернових культур: монографія / В. Ф. Камінський, В. Ф. Сайко, М. В. Душко, Н. М. Асанішвілі та ін. Київ : Видавничий дім «Вініченко», 2017. 580 с.

10. Никитишен В. И. Агрохимические основы эффективного применения удобрений в 
интенсивном земледелии. Москва: Наука, 1984. 214 с.

11. Носко Б. С. Сучасні проблеми фосфору в землеробстві і шляхи їх розв'язання. Вісник аграрної науки. 2017. № 6. С. 5-12.

12. Носко Б. С., Бука А. Я., Юрко К. П. Оптимізація азотного живлення рослин при інтенсивних технологіях. За ред Б. С. Носка, А. Я. Буки. Київ: Урожай, 1992. 136 с.

13. Оптимальные параметры плодородия почв: монография. Под ред. Т. Н. Кулаковской. Москва: Колос, 1984. 270 с.

14. Пасічник Н. А., Степанко А. В. Калійне живлення рослин кукурудзи за різних систем застосування добрив. Рослинництво та трунтознавство. 2016. № 235. С. 204-209.

15. Церлинг В. В. Диагностика питания сельскохозяйственных культур: Справочник. Москва: Агропромиздат, 1990. 235 с.

16. Чабан В.І., Клявзо С.П., Подобед О.Ю. Вміст хімічних елементів в рослинах кукурудзи та оцінка мінерального живлення. Бюлетень Інституту сільського господарства степової зони НААН України. 2014. № 7. С. 27-32.

Дата надходження статті до редакиії: 09.03.2020

Рецензування 02.04.2020 Прийняття в друк: 22.06.2020

\author{
Asanishvili N.M. ${ }^{1}$ \\ PhD (Agric.) \\ Scientific Secretary \\ E-mail : nadia-asanishvili@ukr.net \\ Buslaieva N.H. ${ }^{1}$ \\ PhD (Agric.) \\ E-mail : nataliyabuslaeva@ukr.net \\ Senior Research \\ Shliakhturova S.L. ${ }^{1}$ \\ Researcher \\ E-mail : stopasv@ukr.net \\ ${ }^{I}$ National Scientific Center "Institute of Agriculture of NAAS» \\ Chabany, Kyevo-Svyatoshunskyi district, Kyiv region, Ukraine
}

\title{
INFLUENCE OF AGROCHEMICAL LOAD ON PLANT SUPPLY OF FOOD ELEMENTS AND YIELD OF MAIZE IN THE FOREST- STEPPE
}

\begin{abstract}
The article presents the results of research on the optimization of the supply of maize plants with the main nutrients under different agrochemical loads in the Forest-Steppe. The aim of the research was to establish the effect of different doses of mineral fertilizers and by-products of the predecessor as fertilizers on the supply of plants with nitrogen, phosphorus and potassium and corn yield. The research was carried out during 2016-2019 on dark gray wooded soil of the Forest-Steppe with the use of field, chemical, calculation-weight and mathematical-statistical methods. It were found that long-term growing of agricultural crops for 30 years under different agrochemical loading in crop rotation on dark gray wooded soil of the Forest-Steppe led to the creation of different agrochemical backgrounds. According to the results of soil and plant diagnostics, it has been established that nitrogen is the limiting nutrient for growing corn. In the variants with application of increased $\left(N_{180} P_{120} K_{180}\right)$ and high $\left(N_{240} P_{120} K_{240}\right)$ norms of mineral fertilizers against the background of byproducts of the predecessor (winter wheat straw), where the highest yield of corn is formed - 11.21-12.10 $t /$ ha, mobile phosphorus content $20 \mathrm{~cm}$ layer of soil was very high, mobile potassium - high, easily hydrolyzed nitrogen - very low. In these variants, maize plants in stages BBCH 16, 19 and 65 accumulated the optimal amount of nitrogen, and the content of phosphorus and potassium showed optimal and high supply during the growing season for the application of mineral fertilizers in the norms above $N_{60} P_{45} K_{60}$.
\end{abstract}


According to the results of correlation and regression analysis, the decisive role of nitrogen and potassium in the formation of corn productivity was confirmed. Mathematical models have been constructed that make it possible to predict the level of maize yield depending on the content of chemical elements in the soil and plants at the early stages of $\mathrm{BBCH}$ development.

Keywords: corn, soil and plant diagnostics, nitrogen, phosphorus, potassium, yield, growing technology.

\section{References}

1. Berezhniak, Ye. M. (2013). Efektyvnist alternatyvnykh system udobrennia za riznoho obrobitku $\mathrm{v}$ lantsi polovoi sivozminy. Naukovi pratsi Instytutu bioenerhetychnykh kultur $i$ tsukrovykh buriakiv, 17 (II), 110-113. (in Ukrainian)

2. Bykin, A. V. \& Tarasenko, O. V. (2014). Vplyv udobrennia na produktyvnist kukurudzy na zerno za priamoi sivby. Naukovi dopovidi Natsionalnoho universytetu bioresursiv i pryrodokorystuvannia Ukrainy, 3. http://nbuv.gov.ua/UJRN/Nd_2014_3_11. (in Ukrainian)

3. Bronnikova, L. F. (2018). Formuvannia azotnoho pozhyvnoho rezhymu gruntu pry vyroshchuvanni kukurudzy na zerno. Silske hospodarstvo ta lisivnytstvo, 1(8), 50-59. (in Ukrainian)

4. Dyomin, E. A. \& Eremin, D. I. (2017). Azotnyj rezhim kukuruzy, vyrashchennoj po zernovoj tekhnologii v lesostepnoj zone Zaural'ya. Vestnik Altajskogo gosudarstvennogo agrarnogo universiteta, 12 (158), 10-16. (in Russian)

5. Koren'kov, D. A. (1990). Mineral'nye udobreniya pri intensivnykh tekhnologiyakh. Moskow: Rosagropromizdat. (in Russian)

6. Kokhan, A. V., Hlushchenko, L. D., Len, O. I. et al. (2019). Produktyvnist sortiv i hibrydiv kukurudzy za riznykh system udobrennia ta bezzminnoho yikh vyroshchuvannia. Visnyk ahrarnoi nauky, 10 (799), 18-23. (in Ukrainian)

7. Kramarev, S. M., Skripnik, L. N., Artemenko, S. F. et al. (2010). Diagnostika mineral'nogo pitaniya kukuruzy. Visnyk Poltavskoi derzhavnoi ahrarnoi akademii, 2, 6-17. (in Russian)

8. Saiko, V. F., Lobas, M. H., Yashovskyi I. V. and al. (1994). Naukovi osnovy vedennia zernovoho hospodarstva. Kyiv: Urozhai. (in Ukrainian)

9. Kaminskyi, V. F., Saiko, V. F., Dushko, M. V. \& Asanishvili, N. M. (2017). Naukovi osnovy efektyvnosti vykorystannia vyrobnychykh resursiv $u$ riznykh modeliakh tekhnolohii vyroshchuvannia zernovykh kultur: monohrafiia. Kyiv: Vydavnychyi dim Vinichenko. (in Ukrainian)

10. Nikitishen, V. I. (1984). Agrokhimicheskie osnovy ehffektivnogo primeneniya udobrenij v intensivnom zemledelii. Moskva: Nauka. (in Russian)

11. Nosko, B. S. (2017). Suchasni problemy fosforu v zemlerobstvi i shliakhy yikh rozv'iazannia. Visnyk ahrarnoi nauky, 6, 5-12. (in Ukrainian)

12. Nosko, B. S., Buka, A. Ya., Yurko, K. P. (1992). Optymizatsiia azotnoho zhyvlennia roslyn pry intensyvnykh tekhnolohiiakh. Kyiv: Urozhai. (in Ukrainian)

13. Kulakovskaya, T. N. (Ed.) (1984). Optimal'nye parametry plodorodiya pochv: monografiya. Moskow: Kolos. (in Russian)

14. Pasichnyk, N. A. \& Stepanko, A. V. (2016). Kaliine zhyvlennia roslyn kukurudzy za riznykh system zastosuvannia dobryv. Roslynnytstvo ta gruntoznavstvo, 235, 204-209. (in Ukrainian)

15. Cerling, V. V. (1990). Diagnostika pitaniya sel'skokhozyajstvennykh kul'tur: Spravochnik. Moskow: Agropromizdat. (in Russian)

16. Chaban, V. I., Kliavzo, S. P. \& Podobed, O. Yu. (2014). Vmist khimichnykh elementiv v roslynakh kukurudzy ta otsinka mineralnoho zhyvlennia. Biuleten Instytutu silskoho hospodarstva stepovoi zony NAAN Ukrainy, 7, 27-32. (in Ukrainian) 